\title{
Alveolar Cells: Incorporation of Carbohydrate into Protein and Evidence for Intracellular Protein Transport
}

\author{
Donald Massaro \\ From the Department of Medicine, Duke University School of Medicine \\ and the Pulmonary Disease Service, Veterans Administration Hospital, \\ Durham, North Carolina
}

\begin{abstract}
A в S T R A C T Alveolar cells incubated with radioactive glucosamine, galactose, and mannose incorporate radioactivity into protein, that is, into material insoluble in cold and hot trichloroacetic acid and not extracted by lipid solvents. This incorporation is incompletely inhibited by puromycin hydrochloride. The kinetics of the subcellular distribution of radioactivity are consistent with a precursor-product relationship between microsomal protein and the protein of particles sedimenting at $15,000 \mathrm{~g}$. It is thus suggested that alveolar cells incorporate these substrates intact into protein at the microsomal level with subsequent transfer of this newly formed material to particles sedimenting at $15,000 \mathrm{~g}$.
\end{abstract}

\section{INTRODUCTION}

The procedure described by Myrvik, Leake, and Oshima (1) and later modified by others (2) allows large numbers of cells to be obtained by lung lavage. Moore and Schoenberg (3) have shown that most of the cells so obtained are derived from the cells that line normal alveoli and, hence, are referred to in this paper as alveolar cells as suggested by Bertalanffy (4). These cells have been studied in some detail with particular regard to their phagocytic, enzymatic, and certain other metabolic functions. Their biosynthetic properties

Address requests for reprints to Dr. Donald Massaro, Department of Medicine, Durham Veterans Administration Hospital, Durham, N. C. 27705.

Received for publication 16 June 1967 and in revised form 13 October 1967. have been studied in less detail, particularly their ability to incorporate radioactive substrates into newly formed protein.

This paper presents the results of an investigation of the in vitro incorporation of radioactivity into protein of cells obtained by lung lavage of $M$. bovis (BCG) treated rabbits (2). Radioactive sugars and glucosamine served as substrates. The experiments demonstrate that these cells do incorporate radioactivity into protein. The kinetics of the subcellular distribution of radioactivity are consistent with a precursor-product relationship (5) between microsomal protein and the protein of particles sedimenting at $15,000 \mathrm{~g}$. It is thus suggested that alveolar cells incorporate the substrates into protein at the microsomal level with subsequent transfer of this newly formed material to particles sedimenting at $15,000 \mathrm{~g}$.

\section{METHODS}

Preparation of alveolar cells. New Zealand, white male rabbits weighing about $2 \mathrm{~kg}$ were given $20 \mathrm{mg}$ of heat-killed BCG intravenously, suspended in a $1 \mathrm{ml}$ solution of $0.9 \%$ sodium chloride and $0.01 \%$ Tween 80 (2). 3-4 wk later the rabbits were sacrificed by air embolism, the trachea clamped, and the lungs, heart, and adherent structures removed from the chest en block and placed on ice. Structures adherent to the trachea and lungs were carefully removed and the external surface of the lungs rinsed with cold tap water.

To collect the alveolar cells, $50 \mathrm{ml}$ of cold Hanks' solution (6) was injected into the clamped trachea. It was then unclamped and the lungs gently kneaded. This procedure was repeated several times and the washings kept on ice. The cells were harvested by centrifuging the washings at $5000 \mathrm{~g}$ for $10 \mathrm{~min}$ at $0^{\circ}$. They were resus- 
pended in 5 volumes ( $\mathrm{v} /$ wet $\mathrm{wt}$ ) of Hanl.s' solution and this suspension was used to make the various reaction mixtures. Examination with the light microscope demonstrated that greater than $85 \%$ of these cells were large mononuclear cells, and remaining cells were lymphocytes, polymorphonuclear leukocytes, and red cells. Electron microscopy demonstrated that about one-half of the cells had abundant laminar bodies characteristic of the so-called type II granular pneumocytes (7).

Incubation of alveolar cells. All incubations were performed the day the cells were collected, in glass vessels at $37^{\circ}$ at $\mathrm{pH} 7.4$ using Hanks' solution as the suspending medium with air as the gas phase. In the experiments on the subcellular site of incorporation of radioactive substrates, the reactions were stopped by adding equal volumes of ice cold Hanks' solution and by maintaining the mixture of $0-4^{\circ}$. Cells to be pulse labeled with glucosamine-1 ${ }^{14} \mathrm{C}$ hydrochloride were incubated with this substrate for $40 \mathrm{~min}$ in Hanks' medium. The reaction was stopped and the cells were washed three times with large volumes of this medium, resuspended, and then reincubated for varying time intervals. In all other experiments the reactions were stopped by the addition of cold $20 \%$ trichloroacetic acid (TCA). The protein was isolated and assayed for radioactivity as described below. The radioactive materials used were DL-leucine- $1-{ }^{14} \mathrm{C}, 1$ D-glucosamine-1- ${ }^{14} \mathrm{C},{ }^{1}$ D-galactose-1- ${ }^{14} \mathrm{C},{ }^{1}$ and $\mathrm{D}$-mannose${ }^{1-{ }^{14} \mathrm{C} .1}$

Subcellular fractionation. All procedures were performed between 0 and $4^{\circ}$. After incubation, the cells were harvested by centrifugation at $1000 \mathrm{~g}$ for $10 \mathrm{~min}$ and resuspended in 10 volumes ( $v /$ wet wt of cells) of medium A, which contained $0.35 \mathrm{M}$ sucrose, $0.035 \mathrm{M} \mathrm{KHCO}_{3}$, $0.004 \mathrm{M} \mathrm{MgCl}$, and $0.025 \mathrm{M} \mathrm{KCl} \mathrm{(8).} \mathrm{Cell} \mathrm{disruption}$ was effected by homogenization in a Potter-Elvejhem homogenizer for 330 -sec periods. The homogenate was centrifuged for $10 \mathrm{~min}$ at $1500 \mathrm{~g}$; the supernatant fluid was removed and saved and the sediment suspended in $3 \mathrm{ml}$ of medium $\mathrm{A}$, homogenized, and centrifuged in an identical fashion. The sediment was then discarded, after which the two supernatant fluids were combined and centrifuged for $10 \mathrm{~min}$ at $15,000 \mathrm{~g}$. The resulting supernatant material was diluted between two and three times $(v / v)$ with medium $B$, which contained $0.9 \mathrm{M}$ sucrose, $0.004 \mathrm{M} \mathrm{MgCl}_{2}$, and $0.025 \mathrm{M} \mathrm{KCl} \mathrm{(8),} \mathrm{and} \mathrm{centri-}$ fuged for $60 \mathrm{~min}$ at $105,000 \mathrm{~g}$ in a Beckman model $\mathrm{L}$ ultracentrifuge 2 to sediment the microsomal fraction. The $105,000 \mathrm{~g}$ microsomal pellets were washed twice with medium $\mathrm{A}$ and suspended by gentle homogenization in this medium. The microsomal supernatant material was designated supernatant fraction.

Protein isolation. To precipitate the protein, equal volumes of cold $20 \%$ TCA were added to the sample to be assayed for radioactivity; these mixtures were allowed to stand in ice for $20 \mathrm{~min}$, and were then centrifuged. The supernatant fluid was decanted, the sedi-

\footnotetext{
1 New England Nuclear Corp., Boston, Mass.

${ }^{2}$ Beckman Instruments, Inc., Spinco Div., Palo Alto, Calif.
}

ment was washed three times with cold $5 \%$ TCA, and then extracted with $2.0 \mathrm{ml}$ of ethyl ether-acetone-chloroform $(2: 2: 1 \mathrm{v} / \mathrm{v})$ at $50^{\circ}$ for $30 \mathrm{~min}$. Organic solvents were removed by decantation, the residues were air dried, and extracted with $5 \% \mathrm{TCA}$ at $90^{\circ}$ for $15 \mathrm{~min}$. The supernatant fluid was removed and saved for determination of ribonucleic acid (RNA). The protein precipitates were dissolved in $0.2-1.0 \mathrm{ml}$ of $0.2 \mathrm{M} \mathrm{NaOH}$ by heating at $80^{\circ}$ for $30 \mathrm{~min}$.

Assay for radioactivity. Radioactivity was measured in $0.1-0.2 \mathrm{ml}$ samples of the $\mathrm{NaOH}$ solution of proteins. To these, 1-2 $\mathrm{ml}$ of hydroxide of hyamine ( $p$-diisobutylcresoxyethoxyethyl) dimethylbenzylammonium hydroxide in methanol, ${ }^{3}$ and subsequently $10 \mathrm{ml}$ of toluene containing $1 \mathrm{mg} / \mathrm{ml}$ of PPO (2,5-diphenyloxazole) ${ }^{1}$ and $0.25 \mathrm{mg} / \mathrm{ml}$ of POPOP ( $p$-bis[2-(5-phenyloxazolyl)benzene] were added. ${ }^{1}$ Counting efficiency was determined by recounting each sample after adding toluene- ${ }^{14} \mathrm{C}$ as an internal standard. All measurements were corrected for efficiency and expressed as disintegrations per minute (dpm). Sufficient counts were obtained to have a counting accuracy of $97 \%$.

Isolation of the sugar components. A quantity of cells $(5 \mathrm{ml})$ was incubated at $37^{\circ}$ for $2 \frac{1}{2} \mathrm{hr}$ with $40 \mu \mathrm{c}$ of glucosamine-1- ${ }^{14} \mathrm{C}$. The reaction was stopped by chilling and the cells harvested by centrifugation at $1000 \mathrm{~g}$ for $10 \mathrm{~min}$, whereupon they were homogenized in $4 \mathrm{ml}$ of water. TCA $(20 \%)$ was added in a volume equal to the total volume of the homogenate and the mixture allowed to stand on ice for $20 \mathrm{~min}$. The insoluble material was collected by centrifugation and washed several times with water. The residue was hydrolyzed at $80^{\circ}$ for one hr in $0.1 \mathrm{~N} \mathrm{HCl}$, and the remaining residue was hydrolyzed in $2.0 \mathrm{~N} \mathrm{HCl}$ at $100^{\circ}$ for $6 \mathrm{hr}$. $\mathrm{HCl}$ was removed from both hydrolysates by repeatedly bringing them to dryness in a rotary evaporator at $25^{\circ}$. Material remaining was suspended in water for paper chromatography. This procedure was repeated using galactose $-1-{ }^{14} \mathrm{C}$ as the substrate.

The material was subjected to descending chromatography on Whatman No. 1 paper with butanol-pyridinewater ( $6: 4: 3$ by volume) and ethyl acetate-pyridinewater (10:4:3 by volume). Glucosamine, galactose, mannose, glucose, fucose, $N$-acetyl-glucosamine, and $N$-acetyl-galactosamine were run as standards. 4 Sugars were detected with silver nitrate (9) and the hexosamines and $N$-acetylhexosamines by the method of Partridge (10). Radioactivity was located by an actigraph III paper-strip scanner. ${ }^{5}$

Chemical methods. Ribonucleic acid was measured using soluble yeast RNA ${ }^{6}$ as a standard (11). Crystallized bovine albumin 4 was used as the standard for the protein determinations (12). Estimates of variances were carried out by conventional methods (13).

\footnotetext{
3 Packard Instrument Co., Inc., Downers Grove, Illinois.

4 Mann Research Laboratories, Inc., N. Y.

5 Nuclear Chicago Corp., Des Plaines, Ill.

- General Biochemicals, Chagrin Falls, Ohio.
} 


\section{RESULTS}

Time curve of substrate incorporation. Fig. 1 shows specific activities of protein of the cells from one rabbit, incubated in one instance with DL-leucine- $1-{ }^{14} \mathrm{C}$ and in the other with D-glucosamine- $1-{ }^{14} \mathrm{C}$. Leucine incorporation is linear for 40 min after which it rises asymptotically. The curve of glucosamine incorporation rises less steeply initially, the ascending limb assuming a sigmoid shape. This delay in initial rise in specific activity when glucosamine is the labeled substrate rather than leucine is similar to that reported by Spiro and Spiro for incorporation of these substrates into thyroglobulin (14). They suggested this was due to the larger number of intermediate reactions and pools traversed by the sugar, compared to leucine, before incorporation into protein.

pH optimum for glucosamine incorporation. Maximum incorporation of glucosamine takes place at about $\mathrm{pH}$ 7.4. The buffers were acetate at $\mathrm{pH} 6.4$ and 6.8 , phosphate at 7.0 and 7.5 , Trismaleate at $\mathrm{pH} 7.6,7.7$, and 7.8. No change in $\mathrm{pH}$ took place during the $20 \mathrm{~min}$ incubation period as measured directly by a micro $\mathrm{pH}$ electrode.

Effect of puromycin on incorporation. Previous work in this laboratory demonstrated that in these

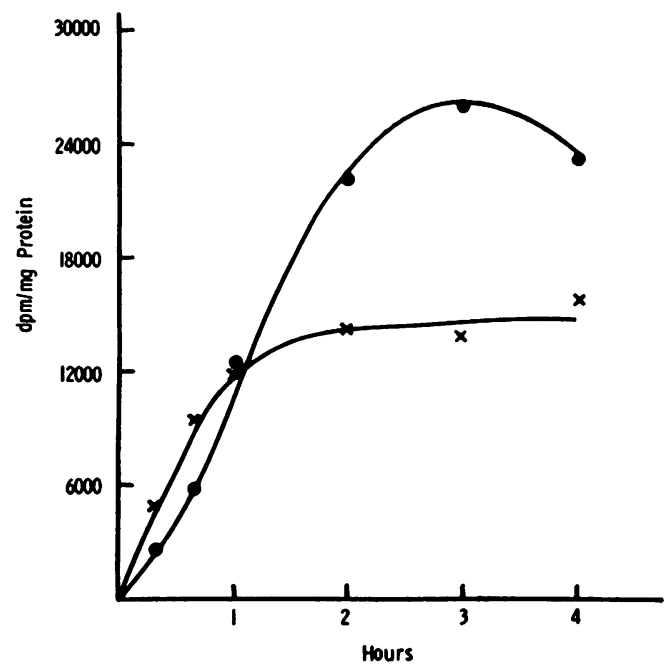

Figure 1 Time course of substrate incorporation into alveolar cell protein. Suspensions : $0.2 \mathrm{ml}$ of alveolar cells in Hanks' solution, $\mathrm{pH} 7.4$, was incubated for the times indicated at $37^{\circ}$ with either D-glucosamine-1-14C (SA, 10.9 $\mathrm{mc} / \mathrm{mmole} ; 0.11 \mu$ mole, $-\bullet)$ or $\mathrm{DL}-$ leucine- $1-{ }^{11} \mathrm{C}(4.77$ $\mathrm{mc} / \mathrm{mmole}$; $0.11 \mu \mathrm{mole}, X-X)$ in a final volume of $0.225 \mathrm{ml}$.
TABLE I

Effect of Puromycin on Incorporation of Radioactivity into Alveolar Cell Protein with Glucosamine-1-14C as Substrate

\begin{tabular}{|c|c|c|c|}
\hline \multirow[b]{2}{*}{ Time } & \multicolumn{2}{|c|}{$\begin{array}{l}\text { Protein specific } \\
\text { activity }\end{array}$} & \multirow[b]{2}{*}{ Inhibition } \\
\hline & Control & $\begin{array}{l}\text { Puromycin } \\
\text { treated }\end{array}$ & \\
\hline $\min$ & \multicolumn{2}{|c|}{$d p m / m g$} & $\%$ \\
\hline 20 & 116 & 92 & 21 \\
\hline 40 & 434 & 258 & 41 \\
\hline 60 & 718 & 267 & 63 \\
\hline
\end{tabular}

cells, puromycin $\left(2.5 \times 10^{-3} \mathrm{M}\right)$ inhibits leucine incorporation into protein by greater than $99 \%$ (15). Table I reveals the effect of puromycin dihydrochloride ${ }^{7}$ in the same concentration on glucosamine incorporation. Maximum inhibition was seen after $60 \mathrm{~min}$ of incubation. These data are consistent with that reported by others $(14,16-$ 21 ), indicating incomplete inhibition of glucosamine incorporation into protein and suggesting that some of the incorporation occurs beyond the ribosomal level.

Subcellular fractionation. Because of the heterogeneity of the material sedimented at $15,000 \mathrm{~g}$, we have named this fraction by the centrifugal force used to sediment the particles rather than assigning it a structural designation. In an attempt to delineate the degree to which the fractionation procedure varied from one incubation mixture to another during an experiment, the total RNA and total protein content of each subcellular fraction was measured for each incubation mixture. The RNA: protein ratio of each subcellular fraction was calculated for each incubation mixture. From this was derived the mean RNA: protein ratio \pm SD for each subcellular fraction in each experiment. In the experiment where glucosamine$1-{ }^{14} \mathrm{C}$ was the substrate, the mean RNA: protein ratio \pm ISD for the $15,000 \mathrm{~g}$, microsomal, and supernatant fractions were $0.05 \pm 0.01,0.15 \pm 0.04$, and $0.01 \pm 0.01$, respectively. With galactose-1${ }^{14} \mathrm{C}$ these values were $0.05 \pm 0.01,0.14 \pm 0.03$, and $0.03 \pm 0.02$, whereas with mannose- $1{ }^{14} \mathrm{C}$ as substrate the ratio of RNA: protein in these fractions was $0.05 \pm 0.01,0.22 \pm 0.07$, and 0.03 \pm 0.02 , respectively. These values indicate rea-

\footnotetext{
${ }^{7}$ Nutritional Biochemical Corp., Cleveland, Ohio.
} 

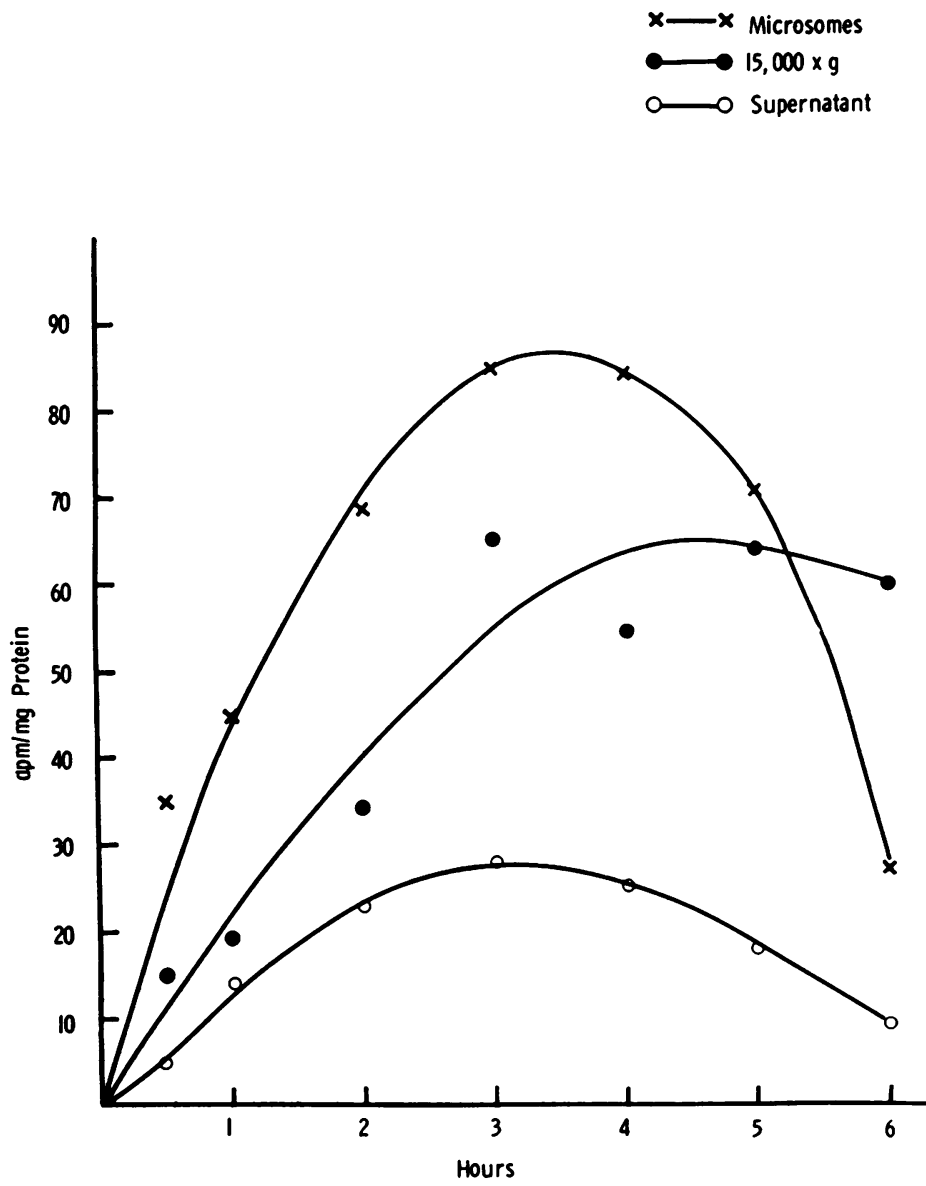

FIGURE 2 Time course of protein specific activity in subcellular fractions of alveolar cells during incubation with D-glucosamine-1-14 C. 2-ml suspensions of alveolar cells were incubated at $37^{\circ}$ and $\mathrm{pH}$ 7.4 with $0.025 \mathrm{ml}$ of $\mathrm{D}$-glucosamine-1 $-{ }^{14} \mathrm{C}$ (SA, $10.36 \mathrm{mc} / \mathrm{mmole} ; 0.12 \mu$ mole) for the times indicated. sonable uniformity of supcellular fractionation among the various incubation mixtures of each experiment.

Subcellular site of incorporation of D-glucosamine-1-14C. Fig. 2 demonstrates the variation with time of protein specific activity in the various subcellular fractions when D-glucosamine- $1-{ }^{14} \mathrm{C}$ was the substrate. Initially, the microsomal fraction had the highest specific activity with a peak occurring between $3-4 \mathrm{hr}$. Thereafter, the specific activity of the protein of this fraction fell and the curve crossed that of the $15,000 \mathrm{~g}$ fraction. The shape of the curves satisfies the criteria for a precursor-product relationship as described by Zilversmit, Entenman, and Fishler (5). Experiments with galactose- $1-^{14} \mathrm{C}$ and mannose- $1{ }^{14} \mathrm{C}$ as substrates demonstrated similar curves.

Fig. 3 reveals the total protein-bound radioactivity in a separate experiment when the reactions were stopped at the indicated times. For the 1 st $8 \mathrm{~min}$, most of the radioactivity was in the mi-

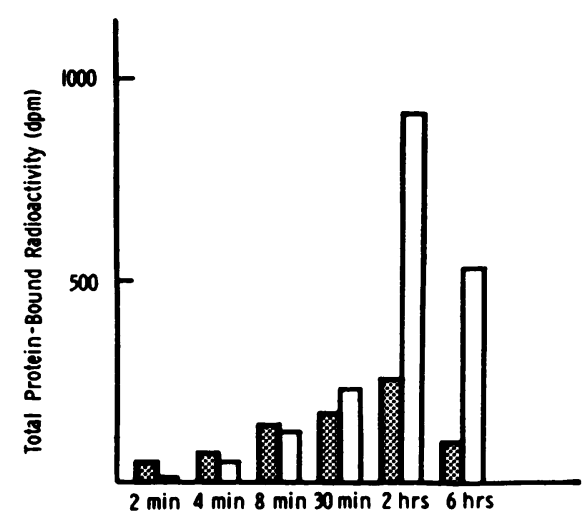

Figure 3 Distribution of total protein-bound radioactivity in subcellular fractions of alveolar cells during incubation with $\mathrm{D}$-glucosamine-1-1" $\mathrm{C}$. 2-ml suspensions of alveolar cells were incubated at $37^{\circ}$ and $\mathrm{pH} 7.4$ with $0.025 \mathrm{ml}$ of D-glucosamine-1 - $^{1 \mathrm{C}} \mathrm{C}$ (SA, $10.9 \mathrm{mc} /$ mode $; 0.11$ $\mu$ mole) for the times indicated. 
crosomal fraction. By $30 \mathrm{~min}$, the $15,000 \mathrm{~g}$ fraction contained most of the protein-bound radioactivity. At $2 \mathrm{hr}$ the total protein-bound radioactivity was threefold greater in the $15,000 \mathrm{~g}$ fraction compared to the microsomal fraction whereas at $6 \mathrm{hr}$, although both fractions had less protein-bound radioactivity, it was now about 5.5 times greater in the $15,000 \mathrm{~g}$ fraction than in the microsomal fraction.

Since these data are consistent with either incorporation of radioactivity into protein at the microsomal level with subsequent transfer to particles sedimenting at $15,000 \mathrm{~g}$, or incorporation at more than one subcellular site but at different rates, the result of pulse labeling the cells was determined. Fig. 4 shows the time course of the protein specific activity after a $40 \mathrm{~min}$ pulsed incubation of $\mathrm{D}$-glucosamine-1-14 $\mathrm{C}$ with alveolar cells. The specific activity of the cell homogenate protein indicates that net incorporation ceased after the $1 \mathrm{st} \mathrm{hr}$ after the pulse. This corresponds with the peak of microsomal protein specific activity, after which the specific activity of the microsomal protein fell below that of $15,000 \mathrm{~g}$ fraction. The specific activity of the protein of this latter fraction continued to rise for $2 \mathrm{hr}$ after the pulse and remained above that of the microsomal fraction, clearly suggesting a precursor-product relationship. The protein specific activity in the supernatant fluid remains relatively constant throughout most of the experiment.

Nature of isotopic compounds appcaring in alveolar cell protcin. In the previous paragraphs it has been implied that the sugars were incorporated intact into protein. It is necessary to determine this because the possibility exists that the radioactivity in the sugar has been converted into radioactive amino acids and hence perhaps protein turnover is also being measured. Thus, one could explain the data in Table I by suggesting that, at early times incorporation of sugar (not inhibited by puromycin) is being measured, whereas at latter times the incorporation of amino acids derived from the radioactive sugars is being measured and, hence the greater inhibition by puromycin. It will be noted in Table I that incorporation of radioactivity has virtually ceased between the 40- and 60-min points. If this inhibition of incorporation of raclioactivity is due to inhibition of amino acid incorporation by puromycin

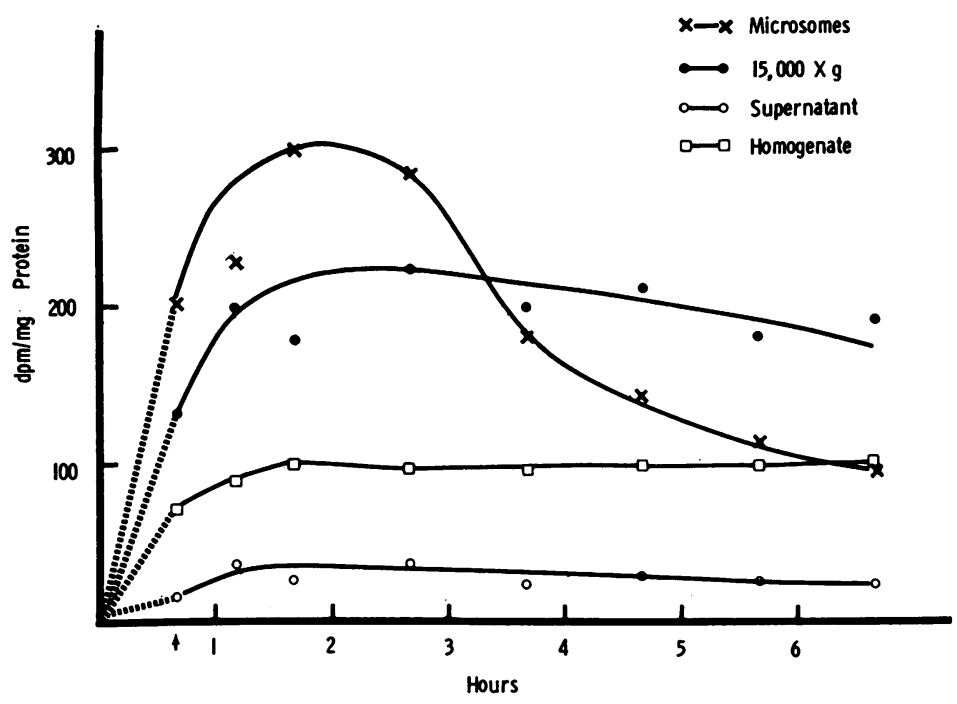

FIgURE 4 : Time course of protein specific activity in subcellular fractions of alveolar cells after a pulsed incubation with D-glucosamine-1- ${ }^{14} \mathrm{C}$. A $20 \mathrm{ml}$ suspension of alveolar cells in Hanks' medium was incubated at $37^{\circ}$ and $\mathrm{pH} 7.4$ with $0.5 \mathrm{ml}$ of $\mathrm{D}$-glucosamine-1 ${ }^{14} \mathrm{C}$ (SA, $10.9 \mathrm{mc} /$ mmole; $2.2 \mu$ moles) for $40 \mathrm{~min}$. The reaction was stopped by chilling the cells which were three times washed with cold Hanks' medium and resuspended to a final volume of $20 \mathrm{ml}$. 2-ml samples were then reincubated for the times indicated. Arrow indicates end of pulse; ---- indicates presumed specific activity during pulsed incubation with D-glucosamine. 


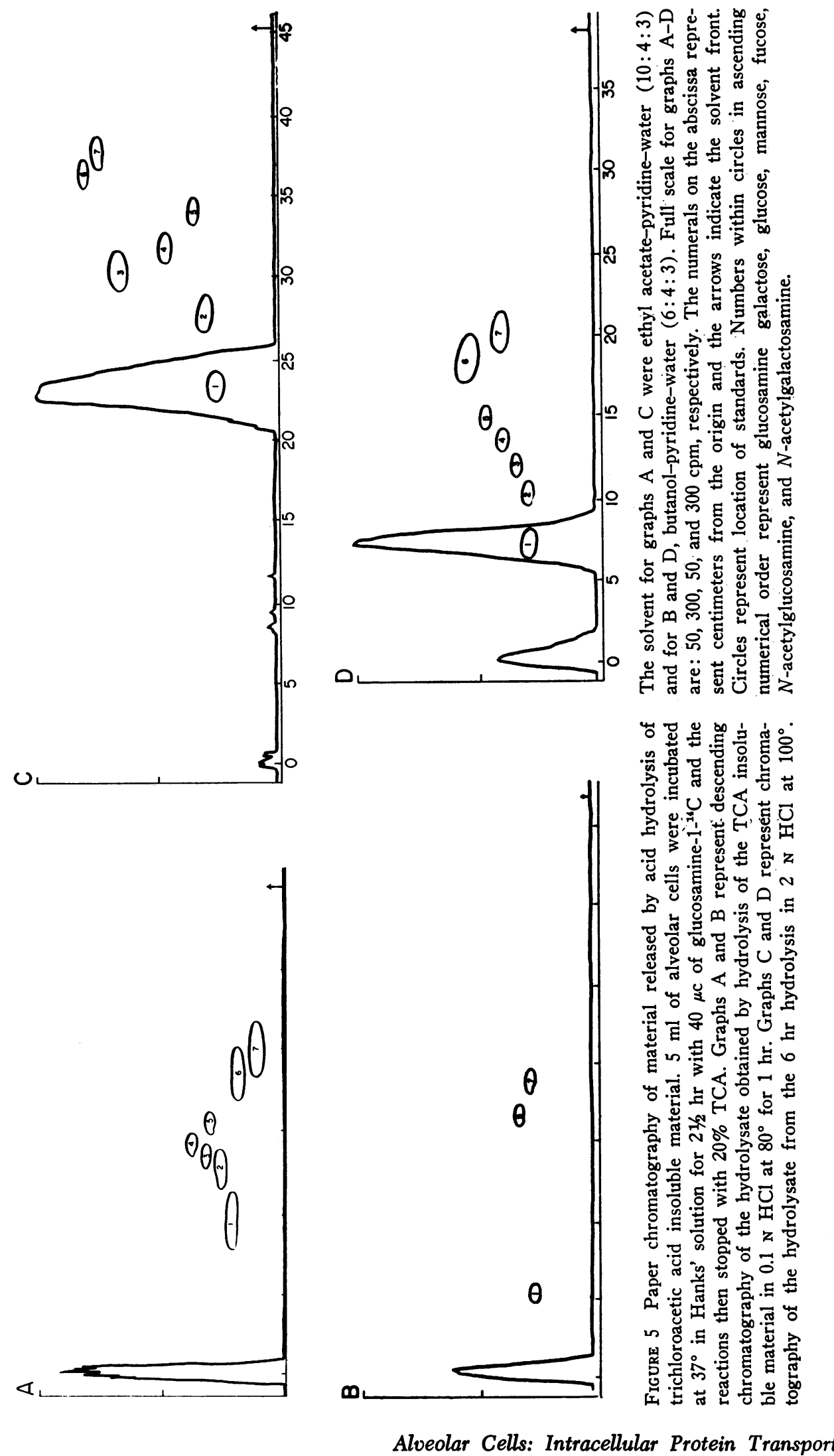


after this $40-60$-minute period, and if conversion to amino acids with subsequent incorporation into protein plays a significant role in our data, the amino acids should be seen in the material to be assayed for radioactivity after $40-60 \mathrm{~min}$ of incubation. To evaluate this possibility, we examined the nature of the isotopic material appearing in alveolar cell protein after a $2 \frac{1}{2} \mathrm{hr}$ incubation with glucosamine- $1-{ }^{14} \mathrm{C}$ and also galactose $-1{ }^{14} \mathrm{C}$. In experiments where the TCA insoluble material was hydrolyzed in $0.1 \mathrm{~N} \mathrm{HCl}$ for $1 \mathrm{hr}$ and chromatographed after removing the $\mathrm{HCl}$, all the radioactivity remained at the origin (Fig. 5). However, when the material hydrolyzed for $6 \mathrm{hr}$ in 2.0 N $\mathrm{HCl}$, and chromatographed, two radioactive peaks were always detected. One small peak remained at the origin and probably represents unhydrolyzed protein. The other radioactive substance moved at the same $R_{f}$ as its nonradioactive standard (Fig. 5). The same results were obtained when galactose- $1{ }^{14} \mathrm{C}$ was the substrate. This indicates that these radioactive substrates were incorporated into protein largely unchanged and that conversion to amino acids did not take place to any detectable extent. Based on previous work by others $(20-23)$, it is probable that the incorporation was through a nucleotide intermediate, but that these compounds were not detected by the isolation procedures used in this study.

\section{DISCUSSION}

Studies on the biosynthesis of proteins in pancreas and liver have produced strong evidence suggesting intracellular transport of secretory proteins $(24,25)$. This has been particularly well studied in the pancreas by Palade and Siekevitz and their associates who have postulated that digestive enzymes are synthesized on ribosomes attached to the rough endoplasmic reticulum. These enzymes are subsequently transported across this membrane to enter the cisternae of the rough endoplasmic reticulum. They later appear at the periphery of the Golgi region, then aggregate in its central condensing vacuoles, after which by progressive filling and condensation of their content, finally become zymogen granules (26-29).

In this regard, it is important to emphasize that the type II granular pneumocytes. which are known to be present in lung washings (3), are thought to perform a secretory function, in particular, to form at least part of the acellular al- veolar lining layer (30). Recent electron microscopic studies have demonstrated the bulk release of material thought to be protein by these cells (31). Sorokin has interpreted the ultrastructural organization of the type II granular pneumocyte to be consistent with the thesis that intracellular transport and extracellular release of proteinaceous material takes place by these cells (32). The kinetics of the subcellular distribution of radioactivity into alveolar cell protein (Figs. 3-5) may be interpreted in several ways. The first of which, consistent in a general way with Sorokin's thesis of transport, indicates that the sugars are incorporated into protein at the microsomal level with subsequent transfer of this newly formed radioactive protein to particles sedimenting at $15,000 \mathrm{~g}$. However, the kinetic data are also consistent with simultaneous incorporation at two or more subcellular sites, but at different rates. Finally, the observed kinetics of incorporation may be due to different degrees of stability of the labeled protein in the different subcellular fractions.

Most previous studies of carbohydrate incorporation into protein have used liver, thyroid, and Ehrlich's tumor ascites cells. Of these studies, those concerned with the subcellular site of incorporation of sugars into protein have indicated that the carbohydrate components of newly formed protein are added to the protein core at the microsomal level $(16-18,33-36)$. This thesis is based primarily on the kinetics of the subcellular distribution of radioactivity. These findings in other tissues indirectly favor the single-site hypothesis for alveolar cells. Furthermore, in light of the kinetics of the pulse-labeling experiments (Fig. 4), the multiple-site alternative would require the unlikely possibility that amino sugar incorporation into protein by particles sedimenting at $15,000 \mathrm{~g}$ increases at the same rate that incorporation into microsomal protein falls, in order to maintain net synthesis in the cell constant as indicated by the constancy of the protein specific activity in the cell homogenate. Because of these considerations, the alternative, which indicates intracellular protein transport in alveolar cells, is considered most probable. However, the data do not eliminate the possibility that the observed kinetics might be due to different degrees of stability of the labeled fractions. 
Although the cells studied are a mixed population, rather than only type II granular pneumocytes (3), it is still intriguing to relate this evidence for intracellular protein transport to the production of the acellular substance lining the alveoli. This lining layer is thought to contain surface active materials (lung surfactants) which are responsible for much of the stability of the small pulmonary air spaces (37). However, the precise contribution of the lung surfactants to the entire acellular lining layer is not clear. Pattle and Thomas (38) and Klaus, Clements, and Havel (39) suggested that this surface-active material is a lipid-protein complex. Biochemical analyses of lung homogenates or washings obtained by lung lavage have shown that most of the surface tension-lowering ability of this presumed complex resides in its phospholipid components, particularly dipalmitoyl lecithin (38-41). Little is known about the biochemical makeup of the protein component of these lung surfactants beyond the demonstration by Abrams and Taylor (42) that it has the electrophoretic mobility of an alpha globulin. The histochemical studies of Macklin (43), Chase (44), and Groniowski and Biczyskowa (45) suggest that carbohydrate-protein moieties are present in the alveolar lining layer, but it is not known if these substances are part of the protein moiety of lung surfactants. However, these findings are particularly interesting because granular pneumocytes thought to synthesize and secrete surfactant contain cytoplasmic inclusions (laminar bodies), which are thought to be rich in carbohydrate-protein material because they are diastase-resistant, periodic acid-Schiff positive (46). These laminar bodies, whose presence is associated with the ability of lung extracts to lower surface tension (47-49), are present in the same subcellular fraction of lung homogenates which contain most of the surface activity (50). One could thus speculate that part of the lung surfactant and, hence the alveolar lining layer, is a carbohydrate-protein moiety synthesized at the microsomal level and transported to the laminar bodies, known to be in the $15,000 \mathrm{~g}$ fraction. This material would then be released from the cell to form the alveolar lining layer. Furthermore, since, in the liver at least, the enzymes required in the final stages of lecithin biosynthesis are microsomal enzymes (51, 52 ), some type of intracellular transport seems to be required for the localization of the surface ac- tivity in the fraction sedimenting at a lower centrifugal force than the microsomes. However, the cells commonly referred to as alveolar macrophages may be responsible for the present findings. Studies with radioautography may answer this question.

\section{ACKNOIVLEDGMENTS}

Supported in part by the Council for Tobacco Research, U. S. A. and the American Thoracic Society.

\section{REFERENCES}

1. Myrvik, A. N.. E. S. Leake, and S. Oshima. 1962. A study of macrophages and epithelioid-like cells from granulomatous (BCG-induced) lungs of rabbits. $J$. Imminol. 89: 745.

2. Cohn, Z. A., and E. Wiener. 1963. The particulate hydrolases of macrophages. J. Exptl. Med. 118: 991.

3. Moore. R. D., and M. D. Schoenberg. 1964. Alveolar lining cells and pulmonary reticuloendothelial system of the rabbit. Am. J. Pathol. 45: 991.

4. Bertalanffy, F. D. 1965. On the nomenclature of the cellular elements of respiratory tissue. Am. Rev. Respirat. Diseasi's. 91: 605.

5. Zilversmit, D. B., C. Entenman, and M. C. Fishler. 1942-43. On the calculation of "turnover time" and "turnover rates" from experiments involving the use of labeling agents. J. Gen. Physiol. 26: 325.

6. Hanks, J. H. 1948. Longevity of chick tissue cultures without removal of medium. J. Cellular Comp. Physiol. $31: 235$.

7. Karrer, H. E. 1956. The ultrastructure of the mouse lung. J. Biophys. Biochcm. Cytol. 2: 241.

8. Allfrey, V. 1959. The isolation of subcellular components. In The Cell. J. Brachet and A. E. Mirsky, editors. Academic Press Inc., New York. 1: 193.

9. Trevelyan, W. E., D. P. Proctor, and J. S. Harrison. 1950. Detection of sugars on paper chromatograms. Nature. 166: 444.

10. Partridge, S. M. 1948. Filter-paper partition chromatography of sugars. Biochem. J. 42: 238.

11. Schneider, W. C. 1956 . Determination of nucleic acids in tissues by pentose analysis. In Methods in Enzymology. S. P. Colowick and N. O. Kaplan, editors. Academic Press Inc., New York. 3: 680.

12. Sutherland, E. W., C. R. Cori, R. Haynes, and N. S. Olsen. 1949. Purification of the hyperglycemic-glycogenolytic factor from insulin and from gastric mucosa. J. Biol. Chem. 180: 825.

13. Basle, S. A. 1956. Documenta Geigy Scientific Tables. J. R. Geigy, editor. 5th edition. 33.

14. Spiro, R. G., and M. J. Spiro. 1966. Glycoprotein biosynthesis: Studies on thyroglobulin. J. Biol. Chem. 241: 1271.

15. Massaro, D. J., A. E. Handler, and L. Bottoms. Alveolar cells: Protein biosynthesis. Am. Rev. Respirat. Diseascs. In press. 
16. Molnar, J., G. B. Robinson, and R. J. Winzler. 1964. The biosynthesis of glycoproteins. J. Biol. Chem. 239: 3157.

17. Cook, G. M. W., M. T. Laico, and E. H. Eylar. 1965. Biosynthesis of glycoproteins of the Ehrlich ascites carcinoma cell membranes. Proc. Natl. Acad. Sci. U.S. $54: 247$.

18. Molnar, J., R. A. Lutes, and R. J. Winzler. 1965. The biosynthesis of glycoproteins. Incorporation of glucosamine- $1-{ }^{14} \mathrm{C}$ into macromolecules by Ehrlich ascites carcinoma cells. Cancer Res. 25: 1438.

19. Lawford, G. R., and H. Schachter. 1966. Biosynthesis of glycoprotein by liver. J. Biol. Chem. 241: 5408 .

20. Roseman, S. 1962. Metabolism of sialic acids and D-mannosamine. Federation Proc. 21: 1075.

21. Molnar, J., G. B. Robinson, and R. J. Winzler. 1964. The biosynthesis of glycoproteins. Glucosamine intermediates in plasma glycoprotein synthesis in livers of puromycin-treated rats. J. Biol. Chem. 239: 3157.

22. McGuire, E. J., G. W., Jourdian, D. M. Carlson, and S. Roseman. 1965. Incorporation of D-galactose into glycoproteins. J. Biol. Chem. 240: 4112.

23. Grebner, E. E., C. W. Hall, and E. F. Neufeld. 1966. Incorporation of $\mathrm{D}$-xylose $-{ }^{14} \mathrm{C}$ into glycoprotein by particles from hen oviduct. Biochem. Biophys. Res. Commun. 22: 672.

24. Palade, G. E., P. Siekevitz, and L. G. Caro. 1962. Structure, chemistry and function of the pancreatic exocrine cell. In Ciba Foundation Symposium on the Exocrine Pancreas. A. V. S. de Reuck and M. P. Cameron, Editors. J. \& A. Churchill Ltd., London. 23.

25. Peters, T., Jr. 1962. The biosynthesis of rat serum albumin. Intracellular phenomena in the secertion of newly formed albumin. J. Biol. Chem. 237: 1186.

26. Siekevitz, P., and G. E. Palade. 1960. A cytochemical study on the pancreas of the guinea pig. In vivo incorporation of leucine- $1-{ }^{14} \mathrm{C}$ into the chymotrypsinogen of various cell fractions. J. Biophys. Biochem. Cytol. 7: 619.

27. Redman, C. P., P. Siekevitz, and G. E. Palade. 1966. Synthesis and Transfer of amylase in pigeon pancreatic microsomes. J. Biol. Chem. 241: 1150.

28. Caro, L. G., and G. E. Palade. 1964. Protein synthesis, storage and discharge in the pancreatic exocrine cell. J. Cell. Biol. 20: 473.

29. Jamieson, J. D., and G. E. Palade. 1966. Role of the Golgi complex in the intracellular transport of secretory proteins. Proc. Natl. Acad. Sci. U. S. 55: 424.

30. Macklin, C. C. 1954 . The pulmonary alveolar mucoid film and the pneumocytes Lancet. 1: 1099.

31. Bensch, K., K. Schaefer, and M. E. Avery. 1964. Science. 145: 1318.

32. Sorokin, S. P. 1967. A morphologic and cytochemical study of the great alveolar cell. J. Histochem. Cytochem. $14: 884$.

33. Sarcione, E. J. 1964. The initial subcellular site of incorporation of hexoses into liver protein. J. Biol. Chem. 239: 686.
34. Molnar, J., G. B. Robinson, and R. J. Winzler. 1965. Biosynthesis of glycoproteins. The subcellular sites of incorporation of glucosamine- $1-{ }^{14} \mathrm{C}$ into glycoproteins in rat liver. J. Biol. Chcm. 240: 1882.

35. Sinohara, H., and H. H. Sky-Peck. 1965. Soluble ribonucleic acid and glycoprotein biosynthesis in the mouse liver. Biochem. Biophys. Acta. 101: 90.

36. Helgeland, L. 1965. Incorporation of radioactive glucosamine into microsomal fractions isolated from rat liver. Biochem. Biophy's. Acta. 101: 106.

37. Pattle, R. E. 1965. Surface lining of lung alveoli. Phy'siol. Rcz'. 45: 48 .

38. Pattle, R. E., and L. C. Thomas. 1961. Lipoprotein composition of the film lining the lung. Nature. 189: 844.

39. Klaus, M. H., J. A. Clements, and R. J. Havel. 1961. Composition of surface-active material isolated from beef lung. Proc. Natl. Acad. Sci. U. S. 42: 1858.

40. Fugiwara, T., H. Hirono, and T. Arakawa. 1965. Chemical identification of the surface-active material isolated from calf lung. Tohoku J. Exptl. Med. 85: 33.

41. Morgan, T. E., T. N. Finley, and H. Failkow. 1965. Comparison of the composition of the surface activity of "alveolar" and whole lung lipids in the dog. Biochem. Biophys. Acta. 106: 403.

42. Abrams, M. E., and F. B. Taylor. 1964. Isolation and quantitative estimation of pulmonary surface active lipoprotein and its interaction with fibrinogen. Physiologist. 7: 78.

43. Macklin, C. C. 1954 . The pulmonary alveolar mucoid film and the pneumocytes. Lancet. 1: 1099.

44. Chase, W. H. 1959. The surface membrane of pulmonary alveolar walls. Exptl. Cell Res. 18: 15.

45. Groniowski, J., and W. Biczyskowa. 1964. Structure of the alveolar lining film of the lungs. Nature. 204: 745.

46. Buckingham, S., W. F. McNary, Jr., and S. C. Sommers. 1964. Pulmonary alveolar cell inclusions: Their development in the rat. Scicnce. 145: 1192.

47. Buckingham, S., and M. E. Avery. 1962. Time of appearance of lung surfactant in the foetal mouse. Nature. 193: 688.

48. Woodside, G. L., and A. J. Dalton. 1958. The ultrastructure of the lung tissue from newborn and embryo mice. J. Ultrastruct. Res. 2: 28.

49. Pattle, R. E. 1961. The formation of a lining film by foetal lungs. J. Pathol. Bacterial. 82: 333.

50. Klaus, M., O. K. Reiss, W. H. Tooley, C. Piel, and J. A. Clements. 1962. Alveolar epithelial cell mitochondria as source of the surface-active lung lining. Science. 137: 750 .

51. Bremer, J., and D. M. Greenberg, 1961. Methyl transferring enzyme system of microsomes in the biosynthesis of lecithin (phosphatidylcholine). Biochem. Biophys. Acta. 46: 205.

52. Wilgram, G. F., and E. P. Kennedy. 1963. Intracellular distribution of some enzymes catalyzing reactions in the biosynthesis of complex lipids. J. Biol. Chem. 238: 1615. 